\title{
Density, biomass and productivity of small mobile invertebrates in a wide range of coastal habitats
}

\author{
Adam Cowles ${ }^{1, *}$, Judi E. Hewitt ${ }^{2}$, Richard B. Taylor ${ }^{1}$ \\ ${ }^{1}$ Leigh Marine Laboratory, The University of Auckland, PO Box 349, Warkworth 0941, New Zealand \\ ${ }^{2}$ National Institute of Water and Atmospheric Research, PO Box 11-115, Hamilton, New Zealand
}

\begin{abstract}
Density, biomass and productivity of small (0.5 to $8.0 \mathrm{~mm}$ ) mobile invertebrates were estimated within 34 diverse coastal habitats occurring along $80 \mathrm{~km}$ of coastline in temperate northeastern New Zealand. These habitats ranged from the high shore to $20 \mathrm{~m}$ depth and included hard, soft and macroalgal substrates. The structurally complex and food-rich coralline algal turf and sandy beach seaweed wrack were the most densely populated and productive habitats, while intertidal sands tended to be most depauperate in mobile fauna. Temporal consistency in results was demonstrated for 4 habitats sampled seasonally for 2 yr. After adjusting for habitat extents, rankings of density, biomass and productivity of fine-scale habitats amalgamated into broad-scale habitats were: subtidal rocky reef $>$ intertidal rocky reef $>$ subtidal soft sediments or intertidal estuary $>$ sandy beach. Total productivity of mobile invertebrates was greater in hard- than soft-bottom habitats. Gastropods numerically dominated most hard-bottom habitats, and gammarid amphipods dominated most softbottom habitats. Communities of broad habitat types were reasonably discrete in multivariate space.
\end{abstract}

KEY WORDS: Secondary productivity $\cdot$ Beach-cast wreck $\cdot$ New Zealand $\cdot$ Rocky reef $\cdot$ Soft-sediment Coralline algal turf

Resale or republication not permitted without written consent of the publisher

\section{INTRODUCTION}

Small mobile invertebrates $(<10 \mathrm{~mm})$ are abundant in many coastal benthic habitats, where they play a number of important ecological roles. One of these is to provide a pathway for energy and materials to flow from primary producers to predators such as small fishes (Edgar \& Moore 1986, Taylor 1998). The relative magnitudes of fluxes through small mobile invertebrates in different habitats can be compared by estimating community-level productivity, the rate at which biomass is elaborated per unit area per time. Productivity is thus the rate at which organic matter is potentially made available to predators such as fishes. Productivity also constitutes a broader index of 'ecological activity', because the rate of production is proportional to rates of other metabolic functions such as food consumption and nutrient excretion (Peters 1983).

A comparison of community-level productivities across common coastal benthic habitats would indicate the relative potential value of each habitat as a food source for small benthic and demersal fishes (Edgar \& Shaw 1995), as many feed primarily on mobile invertebrates $>0.5$ mm (Jones 1988, Edgar \& Shaw 1995). It would also identify habitats, and their key characteristics, in which small mobile invertebrates, by transforming large quantities of energy and materials, may be having functional impacts on community structure that would merit further investigation using experiments (e.g. Duffy \& Hay 2000).

To our knowledge, a broad survey of this kind has not previously been done on a systematic basis for any region, even though 'snapshot' allometric methods (e.g. Edgar 1990a) make estimating the communitylevel productivity of small mobile invertebrates fairly straightforward. Comparing existing productivity data between habitats is difficult and introduces additional error to estimations, as published values were obtained using a variety of methods and animal size classes and were conducted in different locations and seasons (e.g. Cusson \& Bourget 2005). 
The present paper quantifies the composition, density, biomass and productivity of small mobile invertebrates in most commonly occurring intertidal and shallow subtidal $(<20 \mathrm{~m}$ depth $)$ habitats in temperate northeastern New Zealand. Data are presented for 34 fine-scale habitats (e.g. seagrass sediment, intertidal coralline algal turf) and are also amalgamated into 5 broad-scale habitats (intertidal estuary, intertidal rocky reef, sandy beach, subtidal rocky reef and subtidal soft sediments) after scaling for the relative extents of the fine-scale habitats nested within them. Based on previous studies, we hypothesised that mobile invertebrate abundances, biomasses and/or productivities would be higher in habitats that were: (1) food-rich versus poor (e.g. Vetter 1995); (2) structurally complex versus structurally simple, due to the provision of refuge from predators or physical factors by the former (e.g. Coull \& Wells 1983); (3) rocky bottom versus soft sediment, due to the former's greater stability and suitability for hosting of seaweeds (Ricciardi \& Bourget 1999); and (4) subtidal versus intertidal, due to the harsher and more variable physical environment of the latter.

\section{MATERIALS AND METHODS}

Study sites. Composition, density, estimated biomass and estimated productivity of all mobile invertebrates retained on a $0.5 \mathrm{~mm}$ mesh sieve but small enough to pass through an $8 \mathrm{~mm}$ sieve were surveyed within all commonly occurring coastal habitats, ranging from the high tide mark to $20 \mathrm{~m}$ depth on the northeastern coast of New Zealand (see Fig. 1 and Appendix 1 for list of habitats). Some of the names we gave to the fine-scale habitats require explanation. 'Mangrove' is Avicennia marina, 'pneumatophores' are the aerial roots of Avicennia marina, 'seagrass' is Zostera capricorni, 'Carpophyllum plumosum' is a fucalean brown seaweed, 'Ecklonia radiata' is a small laminarian brown seaweed (kelp), 'Perna canaliculus' is a large mytilid bivalve, 'Xenostrobus pulex' is a small mytilid bivalve, and 'Atrina zelandica' is a large pinnid bivalve. Location details and sampling dates are listed in Appendix 1. Sandy beaches were categorised as 'sheltered' (total wind fetch $<1000 \mathrm{~km}$ ), 'moderately exposed' (1000 to $2500 \mathrm{~km})$, and 'exposed' (>2500 km), with fetch estimated by summing measurements of straight line distances to the nearest land mass made at $10^{\circ}$ intervals. If there was no land within $300 \mathrm{~km}$ of the study site on a given bearing, that bearing was allocated a value of $300 \mathrm{~km}$. Wind characteristics were not factored into fetch calculations as beaches shared the same coastline and had similar aspects (north or east facing).
All sites were situated along an $80 \mathrm{~km}$ stretch of coast line between Ocean Beach ( $35^{\circ} 50^{\prime} 21^{\prime \prime} \mathrm{S}, 174^{\circ} 34^{\prime} 20^{\prime \prime} \mathrm{E}$ )

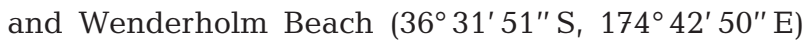
and were sampled between 27 September and 7 December 2006 (austral spring). Most habitats were represented by 5 samples at each of 3 locations. All collecting was done during daylight hours. Water temperature was also recorded at each site on the date of sample collection (measured at low water for intertidal habitats). In the general equation by Edgar (1990a), productivity scales to temperature with an exponent of 0.89 , which is sufficiently close to 1 that temperature does not have a great effect on estimated productivity over the likely range of daily variation experienced in most habitats sampled. For example, if the 'true' temperature at a site was $20^{\circ} \mathrm{C}$, then one-off measurements of 15 or $25^{\circ} \mathrm{C}$ would give productivity estimates that were 77 and $122 \%$ of the 'true' values, respectively.

At each site, all sample locations were haphazardly selected from within the required habitat by placing quadrats or choosing host substrata 'blindly'. Although this process was not strictly random, sample locations were selected without prior knowledge of the fauna likely to be inhabiting them, so the results should not be biased. Where possible, habitat boundaries were avoided, and sample locations were reselected to avoid these if necessary. This was not possible for the relatively small patches of seaweed wrack (see below).

Intertidal habitats. Intertidal habitats were sampled at low tide. Soft sediments were collected using a corer $0.0085 \mathrm{~m}^{2}$ in area by $0.15 \mathrm{~m}$ depth. High-shore stranded seaweed wrack was sampled using a larger corer of $0.0287 \mathrm{~m}^{2}$ by $0.15 \mathrm{~m}$ depth to minimize error attributable to edge effects when sampling highly mobile animals in thick seaweed. Rocky shore habitats were sampled from within a $0.0085 \mathrm{~m}^{2}$ corer and removed from the rock using a metal scraper. Seagrass blades were sampled separately from their associated sediment cores by first cutting them off at the base and removing all blades from the core area. Mangrove pneumatophores were sampled from within the treeline on the seaward fringe of the mangal. All pneumatophores within a $0.1 \mathrm{~m}^{2}$ quadrat were counted, then cut off at the level of the sediment surface.

Subtidal habitats. All samples were collected by a SCUBA diver. Soft sediments were collected as per intertidal sediments. Cores were immediately transferred to bags with $0.2 \mathrm{~mm}$ mesh clamped into one corner to allow drainage. Erect macroalgae were collected by placing a similar bag over the entire plant and removing the holdfast from the bedrock with a knife. An exception to this was the kelp Ecklonia radiata, which was initially bagged and cut away $10 \mathrm{~mm}$ above the holdfast. The holdfast was then removed from the bedrock and sampled separately (due to its 
large size). All macroalgal samples comprised a single individual (except for coralline turf). Collection of animals from coralline turf was conducted using a suction sampler (Taylor et al. 1995) with a sampling area of $0.00785 \mathrm{~m}^{2}$. Macroalgal densities were estimated by counting plants within 10 haphazardly placed $1 \mathrm{~m}^{2}$ quadrats in stands of each species. Beds of the horse mussel Atrina zelandica were sampled by placing a bag over an individual and extracting it from the sediment. Each individual constituted a replicate, and densities of $A$. zelandica were again estimated from ten $1 \mathrm{~m}^{2}$ quadrats placed within the mussel beds.

Seasonal samples. To determine whether differences among habitats were consistent over time, 4 diverse habitats (intertidal and subtidal coralline turf at Matheson Bay, low shore moderately exposed sand at Omaha Beach and intertidal mudflat in the Whangateau Harbour) were sampled at 3 monthly intervals for 2 yr. Sampling methods were as described above.

Sample processing. Samples were preserved in $10 \%$ formalin in seawater containing Rose Bengal vital stain within a few hours of collection. Macroalgae, pneumatophores and horse mussels were later rinsed repeatedly with fresh water until examination of a subset of host substrates under a dissecting magnifying glass showed no associated animals remaining (animals were retained on a $0.1 \mathrm{~mm}$ sieve).

Samples were first rinsed on a $0.5 \mathrm{~mm}$ sieve to remove excess fine sediment and were then washed through a $\log$-series of sieves $(8.0,5.6,4.0,2.8,2.0,1.4,1.0,0.71$ and $0.5 \mathrm{~mm}$ mesh sizes) to size-fractionate the animals (Edgar 1990a). Animals deemed mobile in habit that were retained on mesh sizes of 0.5 to $5.6 \mathrm{~mm}$ were assigned to coarse taxonomic groups and counted. Biomass and productivity of mobile invertebrates were estimated using the general equations by Edgar (1990a), which predict individual biomass (ash-free dry weight, AFDW) as a function of sieve mesh size, and production as a function of individual biomass and water temperature. It is thus important to note that the biomasses and productivities reported in our study are estimates rather than direct measurements.

Fine-scale habitat extents. To estimate density, biomass and productivity within broader-scale habitat types such as 'subtidal rocky reef' or 'sandy beach', we estimated the proportion of these habitats that were comprised of each of the 34 fine-scale habitats sampled. On rocky reefs this was done by recording the habitat type at $1 \mathrm{~m}$ intervals along 5 haphazardly placed $50 \mathrm{~m}$ transects. Three intertidal (Matheson Bay, Tawharanui and Pakiri) and 2 subtidal reefs (Matheson Bay and Ladder Bay), which were deemed to be representative of the reefs included in the present study, were sampled in this way (see Appendix 1). Intertidal estuary and subtidal soft sediments were estimated using exist- ing habitat maps of Whangateau Harbour (Hartill et al. 2000) and Omaha Bay (Taylor \& Morrison 2008), respectively, from which the estimated areal coverage of each habitat type included in the present study was calculated using the program ArcMap GIS. Average densities, etc., within the fine-scale habitats were then weighted by the relative extents of the fine-scale habitats to generate estimates for broad-scale habitats.

Analyses. Graph error bars represent standard errors. Standard errors are based on location means for fine-scale habitats and on habitat means for broadscale habitats. The ordination technique non-metric multidimensional scaling (MDS) was used to visualise relationships between fauna in the different habitats at the assemblage level. The analysis was run on a BrayCurtis dissimilarity matrix derived from fourth-root transformed density data (Field et al. 1982), using Primer V 6.1.6.

\section{RESULTS}

Density

Mean densities of mobile invertebrates varied by 3 orders of magnitude across fine-scale habitats (146 to 125796 ind. $\mathrm{m}^{-2}$ ) (Fig. 1). Coralline turfs contained the highest densities of mobile invertebrates, with subtidal coralline turf being more densely populated than intertidal coralline turf. The habitat with the next highest density was seaweed wrack of moderately exposed beaches. The least densely populated habitats were mostly intertidal sands. Mean densities in broad-scale habitats ranged from 1050 to 28723 ind. $\mathrm{m}^{-2}$, with habitats ranked as follows: subtidal rocky reef $>$ intertidal rocky reef $>$ subtidal soft sediments $>$ intertidal estuary $>$ sandy beach.

\section{Estimated biomass}

Rankings of fine-scale habitats by estimated biomass of mobile invertebrates were similar to density. However, biomass was greatest in the moderately exposed seaweed wrack (Fig. 2). Broad-scale habitats ranged in mean biomass from 0.25 to $2.35 \mathrm{~g} \mathrm{AFDW} \mathrm{m}^{-2}$ and ranked as follows: subtidal rocky reef $>$ intertidal rocky reef $>$ intertidal estuary $>$ subtidal soft sediments $>$ sandy beach.

\section{Estimated productivity}

Average estimated productivity varied by 3 orders of magnitude across fine-scale habitats (0.0005 to 

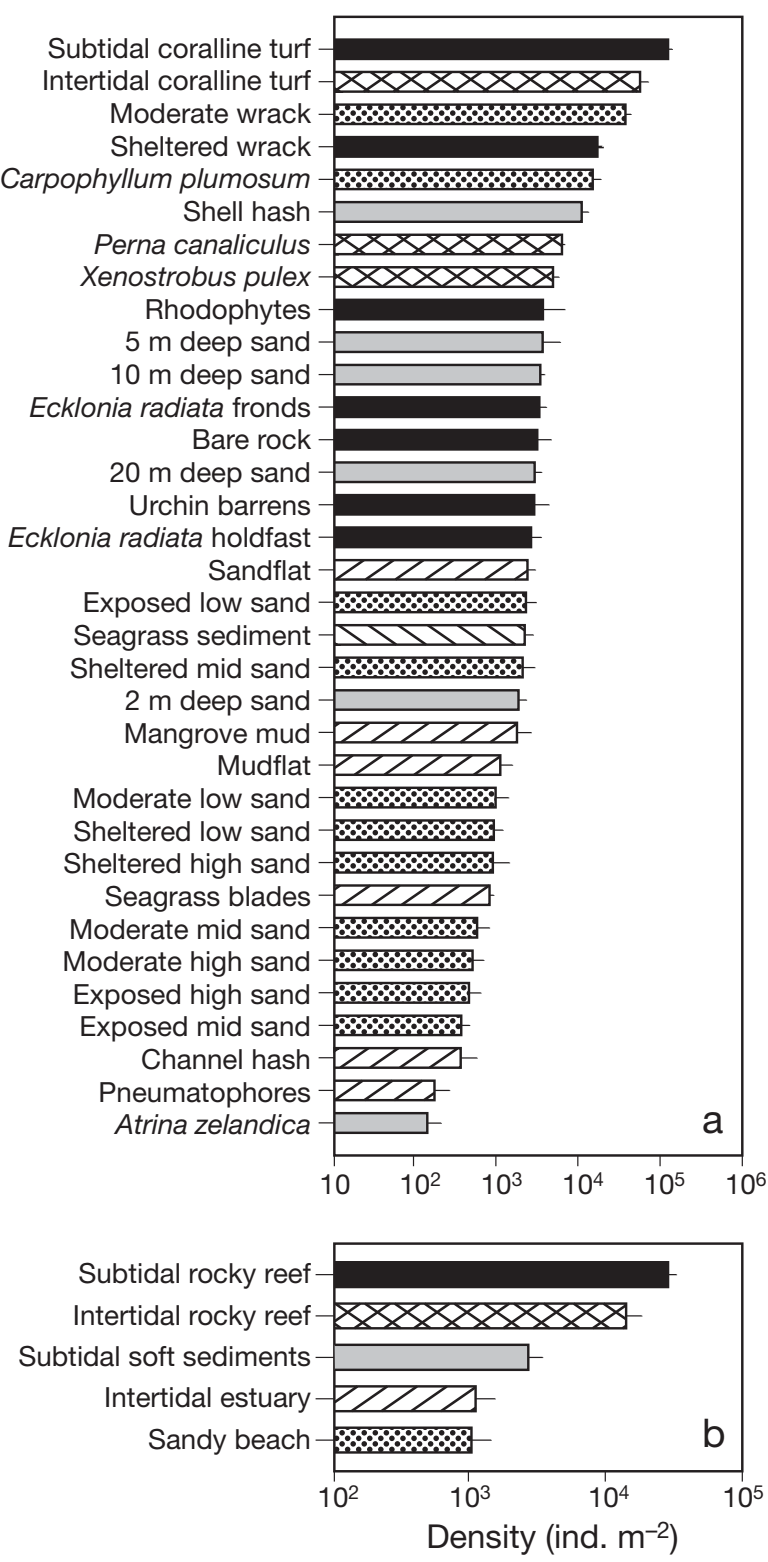

Fig. 1. Densities (ind. $\mathrm{m}^{-2}$ ) of small mobile invertebrates in coastal habitats in northeastern New Zealand: (a) fine-scale and (b) broad-scale habitat levels. Bar patterns in (a) match those in (b). Bars represent averages ( $+1 \mathrm{SE})$. See 'Materials and methods' for explanation of some fine-scale habitat names

$0.22 \mathrm{~g}$ AFDW m${ }^{-2} \mathrm{~d}^{-1}$; Fig. 3). Coralline turf and seaweed wrack were the most productive habitats, in terms of small mobile invertebrates, whilst the intertidal sands were among the least productive habitats. Mean productivity of broad-scale habitats ranged from 0.004 to $0.055 \mathrm{~g}$ AFDW $\mathrm{m}^{-2} \mathrm{~d}^{-1}$ and ranked as follows: subtidal rocky reef $>$ intertidal rocky reef $>$ intertidal estuary $>$ subtidal soft sediments $>$ sandy beach

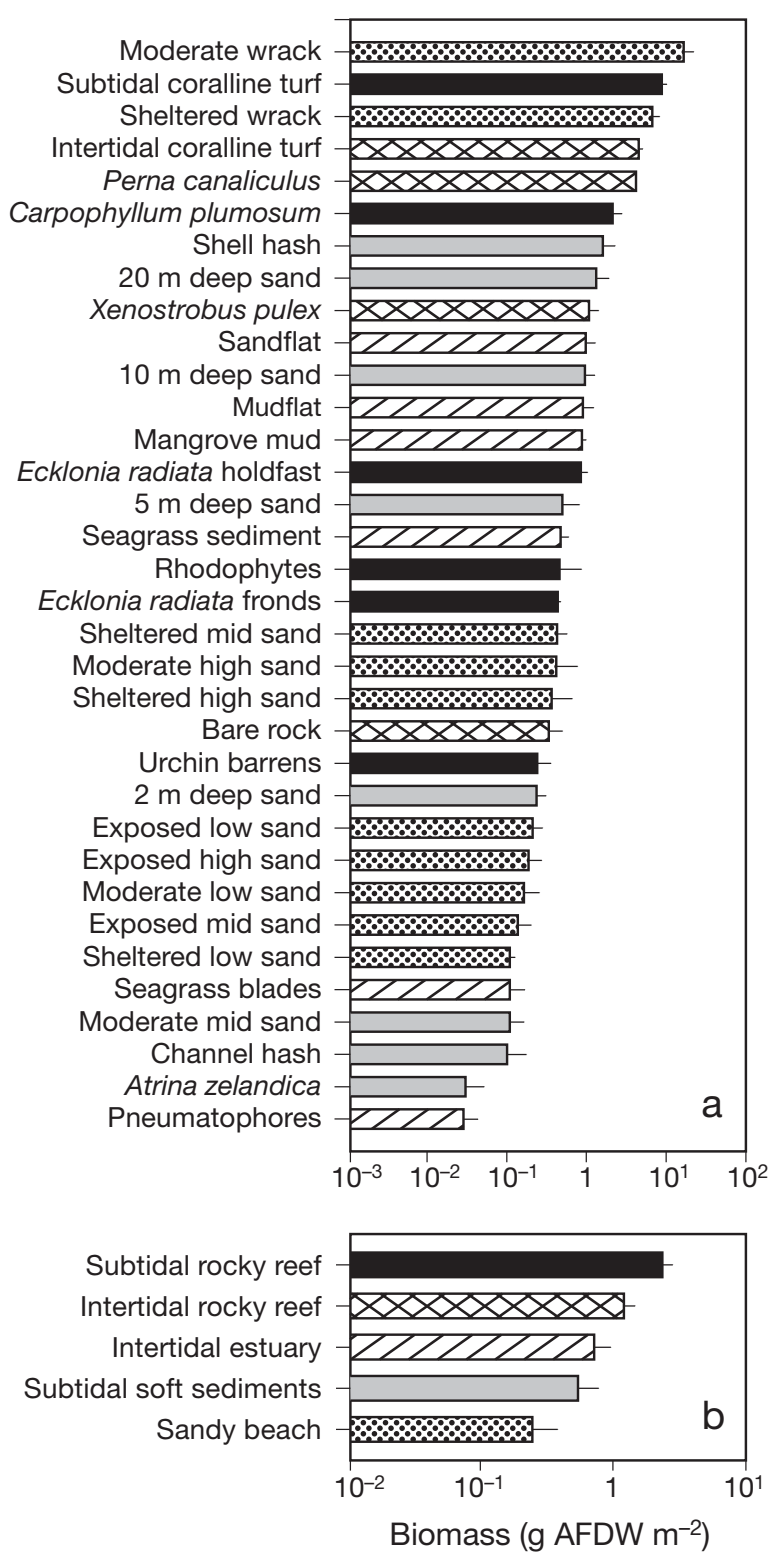

Fig. 2. Biomasses $\left(\mathrm{g} \mathrm{m}^{-2}\right)$ of small mobile invertebrates in coastal habitats in northeastern New Zealand: (a) fine-scale and (b) broad-scale habitat levels. Bar patterns in (a) match those in (b). Bars represent averages ( $+1 \mathrm{SE})$. See 'Materials and methods' for explanation of some fine-scale habitat names. AFDW: ash-free dry weight

\section{Seasonality}

None of the 4 habitats showed strong seasonal patterns of density, estimated biomass, or estimated productivity, although there are indications of seasonality for mudflats (density, biomass and productivity) and for intertidal coralline turfs (biomass). Regardless, the 4 fine-scale habitats ranked consistently by density, biomass and productivity over time (Fig. 4). 
Subtidal coralline turf Moderate wrack Sheltered wrack Intertidal coralline turf Perna canaliculus Carpophyllum plumosum Shell hash Xenostrobus pulex $20 \mathrm{~m}$ deep sand Sandflat $10 \mathrm{~m}$ deep sand Mudflat

Mangrove mud Ecklonia radiata holdfast Rhodophytes $5 \mathrm{~m}$ deep sand Ecklonia radiata fronds Seagrass sediment Bare rock Sheltered mid sand Sheltered high sand Urchin barrens $2 \mathrm{~m}$ deep sand Moderate high sand Exposed low sand Moderate low sand Exposed high sand Sheltered low sand Exposed mid sand Seagrass blades Moderate mid sand Channel hash

Pneumatophores Atrina zelandica

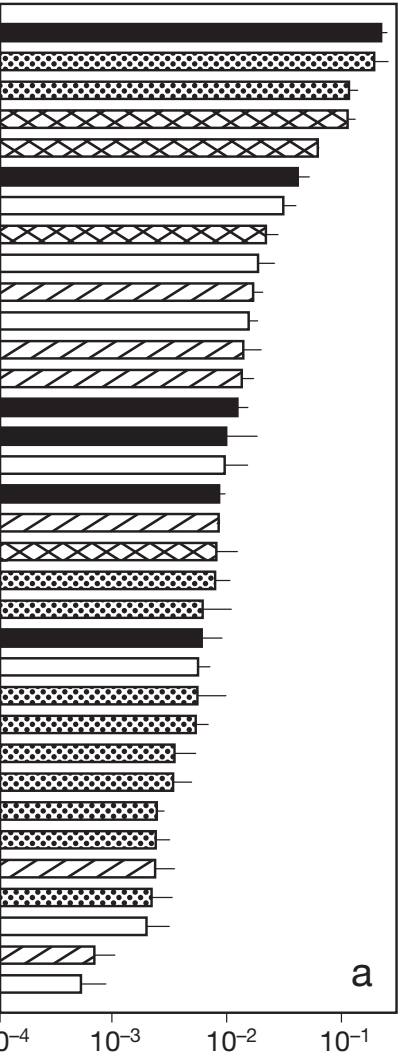

Subtidal rocky reef Intertidal rocky reef Intertidal estuary Subtidal soft sediments Sandy beach

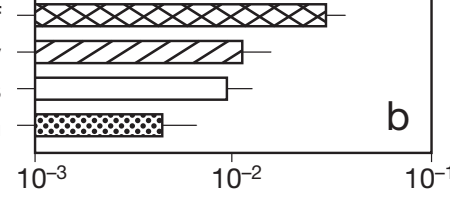

Productivity (g AFDW $\mathrm{m}^{-2} \mathrm{~d}^{-1}$ )

Fig. 3. Productivities (g AFDW $\mathrm{m}^{-2} \mathrm{~d}^{-1}$ ) of small mobile invertebrates in coastal habitats in northeastern New Zealand: (a) fine-scale and (b) broad-scale habitat levels. Bar patterns in (a) match those in (b). Bars represent averages (+1 SE). See 'Materials and methods' for explanation of some fine-scale habitat names

\section{Composition}

Most fine-scale habitats (85\%) were numerically dominated by either gammarid amphipods or gastropods (Fig. 5). Of these 2 taxa, gastropods were the more numerous averaged across all habitats (mean: 4175 ind. $\mathrm{m}^{-2}$ ). Ostracods, polychaetes, isopods, tanaids and nematodes also had high densities when averaged across all habitats (note that the small size of most nematodes meant that the group was likely to have been undersampled by our $0.5 \mathrm{~mm}$ mesh sieve). Some taxa were abundant in only 1 or a few habitats (e.g. ostracods and coleopterans). Soft-sediment habitats tended to be numerically dominated by gammarid amphipods and isopods, whilst hard-bottom communities were dominated by gastropods and gammarid amphipods.

Assemblages of fine-scale habitats grouped clearly in multivariate space according to broad-scale habitat type, with the exception of 1 subtidal soft-sediment fauna, estuarine channel hash (unique in being the only subtidal soft sediment sampled from within an estuary; Fig. 6). Soft-sediment habitats showed some overlap, but were collectively distinct from the rocky reefs. Subtidal and intertidal habitats were also fairly distinct from one another.

\section{DISCUSSION}

To our knowledge this is the first study to systematically survey the composition and density, and to estimate the biomass and productivity, of small mobile invertebrates across a broad spectrum of coastal habitats. Consistent with previous studies, habitats were extremely variable in all these parameters (Edgar 1990b, Taylor 1998, Dolbeth et al. 2003). Density, biomass and productivity each varied by some 3 orders of magnitude, and, in general, habitats ranked similarly according to each parameter. The consistency of ranking of all parameters over $2 \mathrm{yr}$ indicates that results from this 'snapshot' survey are representative of longer time periods.

The method by Edgar (1990a), used to estimate invertebrate biomass and productivity in the present study, has 2 shortcomings that potentially affect our results. (1) There can be significant error around estimates of productivity for individual species. This error should cancel out in diverse assemblages, but may be significant in assemblages that are dominated by a low number of species. In our study, only the seaweed wrack habitat was dominated by a single species, the talitrid amphipod Talorchestia quoyana, which contributed an average of $64 \%$ of total productivity in this habitat. However, production:biomass ratios of 4.7 to 5.7 estimated using Edgar's method for T. quoyana in our samples were similar to others obtained using the more accurate method of cohort analysis on related species from warm-temperate Atlantic and Mediterranean coasts (5.9 to 7.5 for Talorchestia brito [Gonçalves et al. 2003] and 5.7 to 8.2 for Talitrus saltator [Marques et al. 2003]), indicating our results are robust for this species. (2) Edgar's method does not take into account variation in productivity due to food supply, which may potentially lead to underestimates of productivity when food is abundant and overestimates when it is scarce. However, data by Edgar (1990a) indicate that the food supply generally has only a minor effect on the productivity of individuals. For the 41 species used to generate 


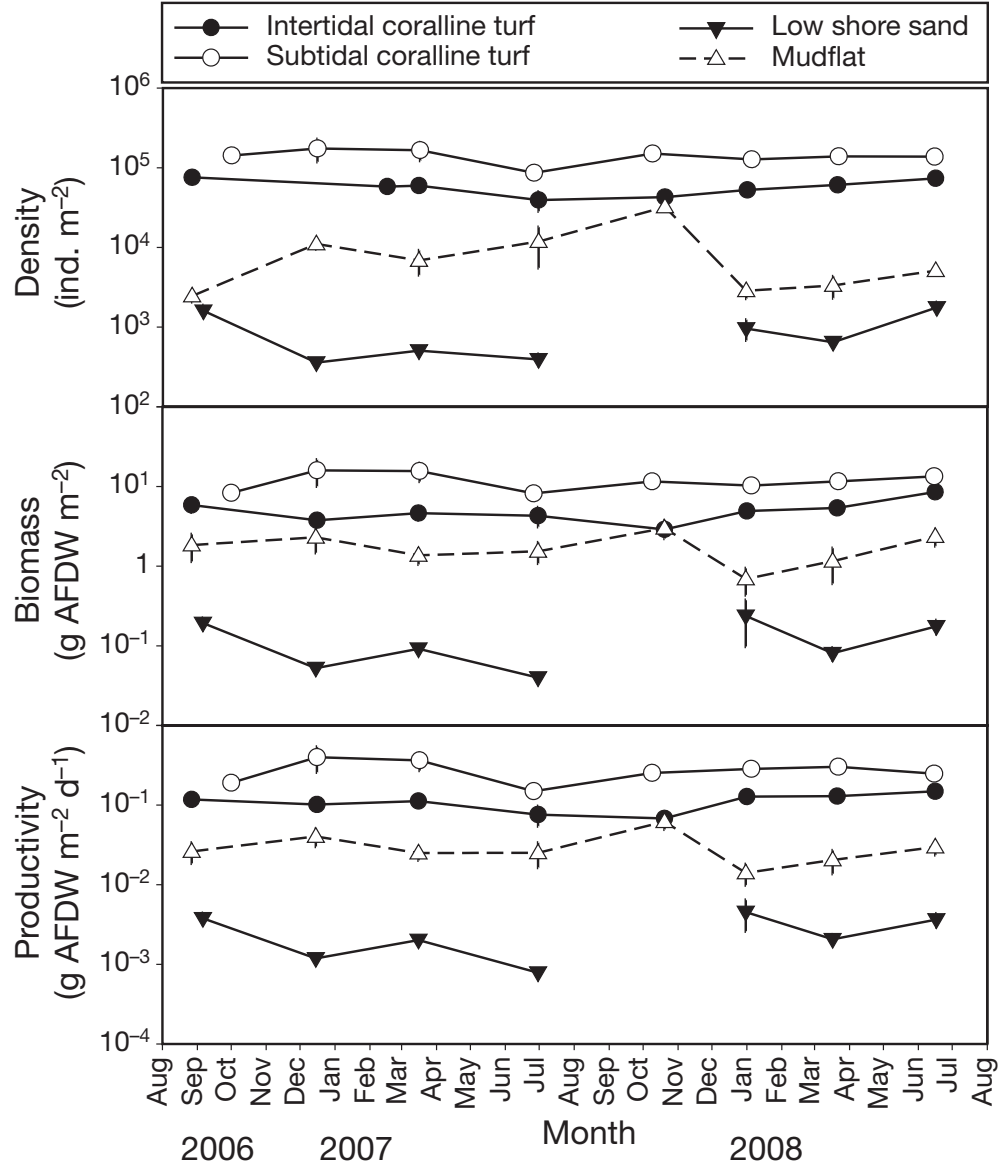

Fig. 4. Density, biomass and productivity of 4 small mobile invertebrate communities from coastal habitats in northeastern New Zealand at 3 monthly intervals over a $2 \mathrm{yr}$ period. Points represent averages $( \pm 1 \mathrm{SE})$

Edgar's general equation, $94 \%$ of the variation in log productivity was explained by body size and temperature alone, leaving only $6 \%$ to be contributed by other factors such as food supply. This implies that high productivity in certain food-rich habitats is due to high numbers of individuals growing at 'normal' growth rates rather than to high growth rates of those individuals. Since Edgar's 41 species were from a wide variety of locations around the world, and lived in a range of habitats, water temperatures and salinities, we believe it is reasonable to assume that variation in food supply also had a relatively minor effect on the productivity of individuals at our sample sites and thus should not have unduly influenced our results.

Coralline turf and stranded seaweed wrack supported the highest densities, estimated biomasses and estimated productivities of small mobile invertebrates. Coralline turfs have previously been found to host productive invertebrate assemblages (Taylor 1998), which support high densities of juvenile carangid, mullid and sparid fishes (Choat \& Kingett 1982). Seaweed wrack is also inhabited by high densities of epifauna and in- fauna (Ince et al. 2007, Lewis et al. 2007, Coupland \& McDonald 2008). Whilst animals in seaweed wrack are unlikely to be a direct source of food for fishes due to their height on the shore, their production can be exported to the subtidal by predators such as crabs (Lewis et al. 2007), and they also subsidise adjacent terrestrial habitats (Polis \& Hurd 1995, Colombini \& Chelazzi 2003). Seaweed wrack can be deposited in vast quantities (Colombini \& Chelazzi 2003) and is potentially one of the most biomass-rich and productive habitats on earth (Coupland \& McDonald 2008).

Coralline turfs and seaweed wrack share key characteristics likely to promote productive mobile invertebrate assemblages ( $\mathrm{Hy}$ potheses 1 and 2). First, they provide abundant food to small mobile invertebrates in the form of detritus. Seaweeds can be very productive (Mann 1973), but relatively little of their production is consumed directly, with the remainder eventually dispersed as detritus (e.g. Branch \& Griffiths 1988). Where it accumulates in large quantities, it is exploited by highly productive assemblages of small crustaceans and other invertebrates, most spectacularly in the thick mats of seaweed detritus in a submarine canyon off California (Vetter 1995). Seaweed detritus is often a more valuable food than the living plant, due to reductions in toughness and polar secondary metabolites and an increase in the nitrogen content (Robertson \& Lucas 1983, Duggins \& Eckman 1997). The seaweed wrack habitat is by definition composed of seaweed detritus, while coralline turf traps seaweed particles within its matrix (Hines 1982).

The structural complexity of coralline turf and seaweed wrack additionally provides shelter from predation and environmental stresses. Mobile invertebrates inhabiting structurally complex environments are often less vulnerable to predation than those associated with more homogenous structure (Heck \& Thoman 1981, Coull \& Wells 1983). Coralline turf provided the best refuge from fish predation of a variety of tidepool habitats tested by Coull \& Wells (1983). The fauna of seaweed wrack is also well concealed from predators such as birds (Lewis et al. 2007). Complex structures have more attachment points and reduce water flow, which facilitates resistance to dislodgement by water movement (Edgar 1983, Taylor \& Cole 1994). Coralline turf is not only rigid and very finely structured, but it is also low lying to the substratum where flow is disrupted and slowed within the benthic boundary layer, and so further reduces the risk of dislodge- 


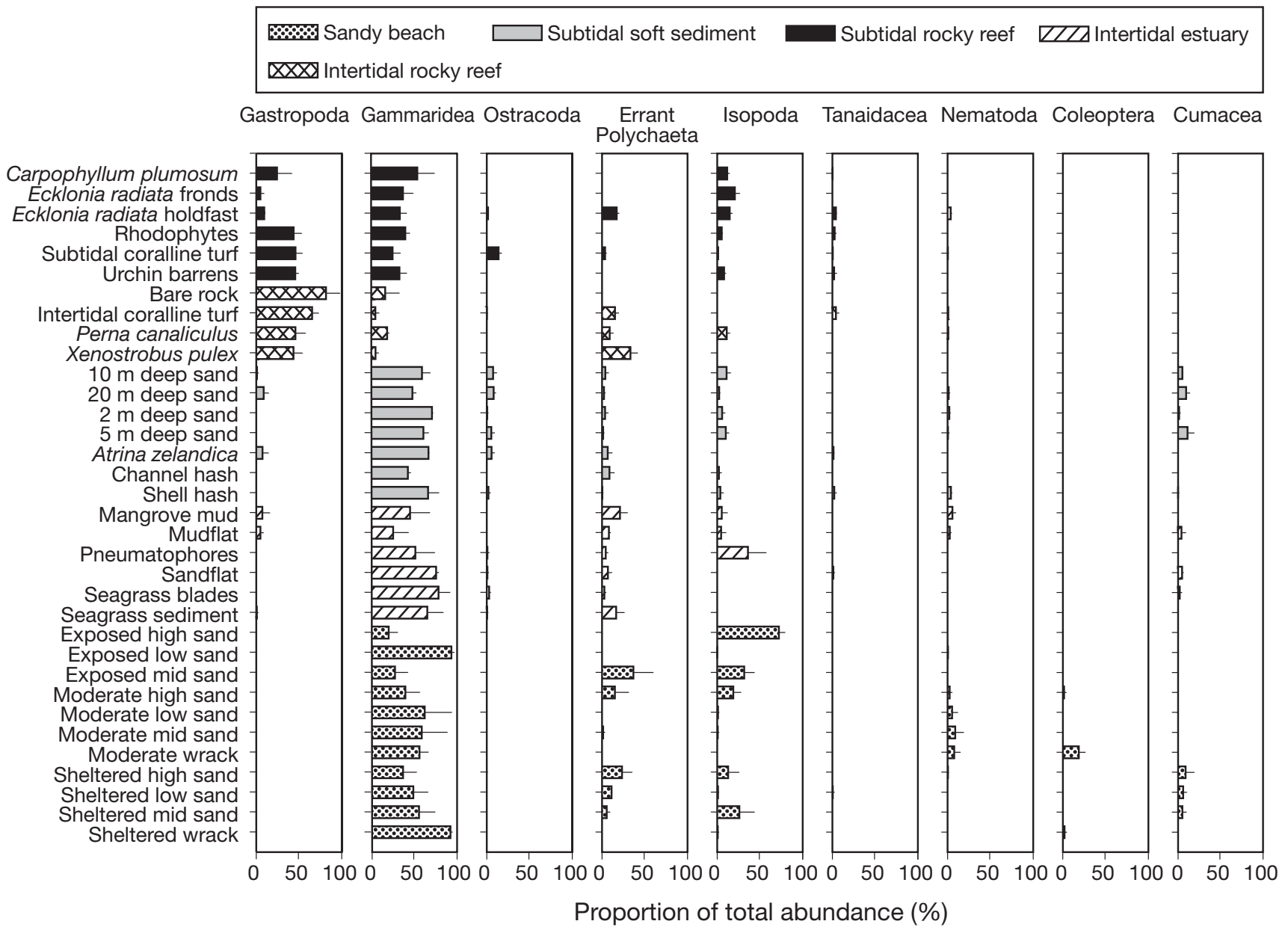

Fig. 5. Contribution to overall mobile invertebrate abundance by the 9 most numerous taxa (from data summed across all habitats) in coastal habitats in northeastern New Zealand, ranked in order of decreasing abundance. Bars represent averages (+1 SE)

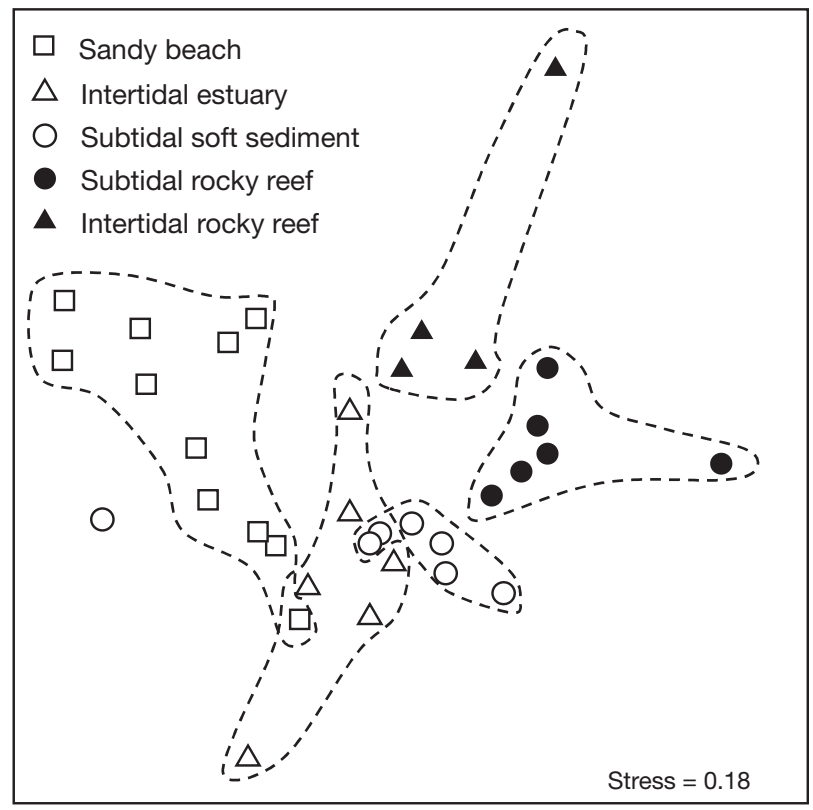

ment. Intertidally, structurally complex habitats may provide better resistance to desiccation. Davenport et al. (1999) reported fewer epifauna remaining in littoral habitats of low fractal dimensions than in complex coralline turf with high water retention during tidal emersion.

At the broader scale, as predicted (Hypotheses 3 and 4), hard-bottom habitats (i.e. rocky reefs) were more productive than soft-sediment habitats, and subtidal habitats tended to be more productive, in terms of mobile invertebrates, than intertidal habitats. The dominance by hard-bottomed habitats may be mediated by seaweeds, which provide complex structure and

Fig. 6. Non-metric multidimensional scaling ordination of assemblages of small mobile invertebrates in fine-scale coastal habitats around northeastern New Zealand. Circles denote subtidal, all other shapes intertidal habitats. Filled symbols indicate hard substrates, hollow symbols soft sediments. Dashed lines define groupings of habitats at broad-scale level 
food to associated invertebrates, and typically require a hard surface to anchor themselves to the seafloor (Lobban \& Harrison 1997). Ricciardi \& Bourget (1999) noted macrofaunal biomass to be greater on rocky shores (which are generally more structurally complex) than sedimentary shores in a global survey. The trend for productivity of mobile invertebrates to be higher in subtidal than intertidal habitats may be due to the less stressful physical environment of the subtidal, which is not exposed to the periodic desiccation and fluctuating temperatures characteristic of intertidal habitats.

Overall, the results of our study were consistent with the hypotheses listed in the 'Introduction', in that productivity tended to be highest in habitats that were food rich, structurally complex, hard bottomed and subtidal.

The density and productivity of mobile invertebrates were lower than expected within seagrass beds and on horse mussels Atrina zelandica. Seagrass often hosts an abundant and productive fauna (Orth 1977, Fredette \& Diaz 1990, Beal et al. 2004); however, in contrast to many studies, we sampled relatively small and patchy intertidal beds (the only ones available in our region). In northern New Zealand, subtidal seagrass beds tend to support more productive animal assemblages than do intertidal beds (M. Morrison pers. comm.). Horse mussel beds are more structurally complex than bare sediment beds; however, only mobile fauna living directly on the mussel shell were sampled in the present study, limiting the type of fauna counted, the available space and the ability of the mussels to provide refuge from predators and hydrodynamic forces. Moreover, macroinvertebrate densities are not always higher within the mussel bed sediment (Cummings et al. 1998), and the influence that these bivalves have on adjacent infauna can be complex and affected by environmental gradients (Cummings et al. 2001, Norkko et al. 2006).

The 3 most abundant taxa we sampled (crustaceans, gastropods and polychaetes) dominate the diets of small benthic and demersal fishes (Russell 1983, Jones 1988, Holbrook et al. 1990, Edgar \& Shaw 1995). With the exception of the seaweed wrack, a highly productive habitat that supports birds and terrestrial animals rather than fishes due to its position on the shore, the productivity rankings of the fine- and broad-scale habitats should thus be a useful indicator of their potential values as food sources for small fishes.

Acknowledgements. This work was supported by a New Zealand Foundation of Research, Science and Technology Output Based Initiative (Foundation Number CO1X0502). We thank S. Cowles for invaluable help in the field, E. Villouta for providing access to his Fetch Effect Analysis software, and the 3 reviewers for their constructive criticism of the manuscript. A.C. thanks the Lord for this diverse and beautiful world that never fails to fascinate.

\section{LITERATURE CITED}

Beal BF, Vadas RL, Wright WA, Nickl A (2004) Annual aboveground biomass and productivity estimates for intertidal eelgrass (Zostera marina L.) in Cobscook Bay, Maine. Northeast Nat 11:197-224

Branch GM, Griffiths CL (1988) The Benguela ecosystem, Part V. The coastal zone. Oceanogr Mar Biol Annu Rev 26: 395-486

Choat JH, Kingett PD (1982) The influence of fish predation on the abundance cycles of an algal turf invertebrate fauna. Oecologia 54:88-95

Colombini I, Chelazzi L (2003) Influence of marine allochthonous input on sandy beach communities. Oceanogr Mar Biol Annu Rev 41:115-159

> Coull B, Wells J (1983) Refuges from fish predation: experiments with phytal meiofauna from the New Zealand rocky intertidal. Ecology 64:1599-1609

Coupland G, McDonald J (2008) Extraordinarily high earthworm abundances in deposits of marine macrodetritus along two semi-arid beaches. Mar Ecol Prog Ser 361: 181-189

> Cummings VJ, Thrush SF, Hewitt JE, Turner SJ (1998) The influence of the pinnid bivalve Atrina zelandica (Gray) on benthic macroinvertebrate communities in soft-sediment habitats. J Exp Mar Biol Ecol 228:227-240

Cummings VJ, Thrush SF, Hewitt JE, Funnell GA (2001) Variable effect of a large suspension feeding bivalve on infauna: experimenting in a complex system. Mar Ecol Prog Ser 209:159-175

Cusson M, Bourget E (2005) Global patterns of macroinvertebrate production in marine benthic habitats. Mar Ecol Prog Ser 297:1-14

Davenport J, Butler A, Cheshire A (1999) Epifaunal composition and fractal dimensions of marine plants in relation to emersion. J Mar Biol Assoc UK 79:351-355

> Dolbeth M, Pardal MA, Lillebo AI, Azeiteiro U, Marques JC (2003) Short- and long-term effects of eutrophication on the secondary production of an intertidal macrobenthic community. Mar Biol 143:1229-1238

Duffy JE, Hay ME (2000) Strong impacts of grazing amphipods on the organization of a benthic community. Ecol Monogr 70:237-263

Duggins DO, Eckman JE (1997) Is kelp detritus a good food for suspension feeders? Effects of kelp species, age and secondary metabolites. Mar Biol 128:489-495

Edgar GJ (1983) The ecology of south-east Tasmanian phytal animal communities. III. Patterns of species diversity. J Exp Mar Biol Ecol 70:181-203

> Edgar GJ (1990a) The use of the size structure of benthic macrofaunal communities to estimate faunal biomass and secondary production. J Exp Mar Biol Ecol 137:195-214

Edgar GJ (1990b) The influence of plant structure on the species richness, biomass and secondary production of macrofaunal assemblages associated with Western Australian seagrass beds. J Exp Mar Biol Ecol 137:215-240

Edgar GJ, Moore PG (1986) Macro-algae as habitats for motile macrofauna. Monogr Biol 4:255-277

$>$ Edgar GJ, Shaw C (1995) The production and trophic ecology of shallow-water fish assemblages in southern Australia. II. Diets of fishes and trophic relationships between fishes and benthos at Western Port, Victoria. J Exp Mar Biol Ecol 194:83-106

> Field JG, Clarke KR, Warwick RM (1982) A practical strategy for analysing multispecies distribution patterns. Mar Ecol Prog Ser 8:37-52

Fredette T, Diaz R (1990) Secondary production within a sea- 
grass bed (Zostera marina and Ruppia maritima) in lower Chesapeake Bay. Estuaries 13:431-440

Gonçalves SC, Marques JC, Pardal MA, Bouslama MF, El Gtari M, Charfi-Cheikhrouha F (2003) Comparison of the biology, dynamics, and secondary production of Talorchestia brito (Amphipoda, Talitridae) in Atlantic (Portugal) and Mediterranean (Tunisia) populations. Estuar Coast Shelf Sci 58:901-916

Hartill B, Morrison M, Shankar U, Drury J (2000) Whangateau Harbour habitat map. Information Series No. 10, National Institute of Water \& Atmospheric Research (NIWA), Auckland

Heck Jr KL, Thoman T (1981) Experiments on predator-prey interactions in vegetated aquatic habitats. J Exp Mar Biol Ecol 53:125-134

Hines A (1982) Coexistence in a kelp forest: size, population dynamics and resource partitioning in a guild of spider crabs (Brachyura, Majidae). Ecol Monogr 52:179-198

Holbrook SJ, Schmitt RJ, Ambrose RF (1990) Biogenic habitat structure and characteristics of temperate reef fish assemblages. Aust J Ecol 15:489-503

Ince R, Hyndes GA, Lavery PS, Vanderklift MA (2007) Marine macrophytes directly enhance abundances of sandy beach fauna through provision of food and habitat. Estuar Coast Shelf Sci 74:77-86

Jones GP (1988) Ecology of rocky reef fish of northeastern New Zealand: a review. NZ J Mar Freshw Res 22: 445-462

Lewis T, Mews M, Jelinski D, Zimmer M (2007) Detrital subsidy to the supratidal zone provides feeding habitat for intertidal crabs. Estuaries Coasts 30:451-458

Lobban CS, Harrison PJ (1997) Seaweed ecology and physiology. Cambridge University Press, Cambridge

Mann KH (1973) Seaweeds: their productivity and strategy for growth. Science 182:975-981

Marques JC, Gonçalves SC, Pardal MA, Chelazzi L and others (2003) Comparison of Talitrus saltator (Amphipoda, Talitridae) biology, dynamics, and secondary production in Atlantic (Portugal) and Mediterranean (Italy and Tunisia) populations. Estuar Coast Shelf Sci 58:127-148

Norkko A, Hewitt JE, Thrush SF, Funnell GA (2006) Conditional outcomes of facilitation by a habitat-modifying subtidal bivalve. Ecology 87:226-234

Orth RJ (1977) Effect of nutrient enrichment on growth of eelgrass-Zostera marina in Chesapeake Bay, Virginia, USA. Mar Biol 44:187-194

Peters RH (1983) The ecological implications of body size. Cambridge University Press, Cambridge

Polis GA, Hurd SD (1995) Extraordinarily high spider densities on islands - flow of energy from the marine to terrestrial food webs and the absence of predation. Proc Natl Acad Sci USA 92:4382-4386

Ricciardi A, Bourget E (1999) Global patterns of macroinvertebrate biomass in marine intertidal communities. Mar Ecol Prog Ser 185:21-35

> Robertson AI, Lucas JS (1983) Food choice, feeding rates, and the turnover of macrophyte biomass by a surf-zone inhabiting amphipod. J Exp Mar Biol Ecol 72:99-124

Russell BC (1983) The food and feeding habits of rocky reef fish of northeastern New Zealand. NZ J Mar Freshw Res $17: 121-145$

Taylor RB (1998) Density, biomass and productivity of animals in four subtidal rocky reef habitats: the importance of small mobile invertebrates. Mar Ecol Prog Ser 172:37-51

Taylor RB, Cole RG (1994) Mobile epifauna on subtidal brown seaweeds in northeastern New Zealand. Mar Ecol Prog Ser 115:271-282

Taylor RB, Morrison MA (2008) Soft-sediment habitats and fauna of Omaha Bay, northeastern New Zealand. J R Soc NZ 38:187-214

Taylor RB, Blackburn R, Evans J (1995) A portable batterypowered suction device for the quantitative sampling of small benthic invertebrates. J Exp Mar Biol Ecol 194:1-7

- Vetter EW (1995) Detritus-based patches of high secondary production in the nearshore benthos. Mar Ecol Prog Ser 120:251-262

Appendix 1. Sampling dates, locations and areas sampled $\left(n=5\right.$ habitat $^{-1}$ site $\left.^{-1}\right)$. Habitat extent is the proportional coverage of that fine-scale habitat type at the location listed (e.g. subtidal coralline turf at Mathesons Bay). Sites with no dates indicated were used for habitat extent estimations only; (-) indicates data are not appropriate for that habitat. C.D.: chart datum

\begin{tabular}{|c|c|c|c|c|c|c|}
\hline Habitat & Location & Coordinates & $\begin{array}{l}\text { Area sampled } \\
\qquad\left(\mathrm{m}^{2}\right)\end{array}$ & $\begin{array}{c}\text { Depth } \\
\text { (m below C.D.) }\end{array}$ & $\begin{array}{l}\text { Collection date } \\
\text { (dd/mm/yy) }\end{array}$ & $\begin{array}{c}\text { Habitat } \\
\text { extent }(\%)\end{array}$ \\
\hline \multicolumn{7}{|l|}{ Intertidal estuary } \\
\hline \multirow[t]{3}{*}{ Mangrove mud } & Whangateau Hr & $36^{\circ} 18^{\prime} 58^{\prime \prime} \mathrm{S}, 174^{\circ} 45^{\prime} 43^{\prime \prime} \mathrm{E}$ & 0.0085 & - & $27 / 09 / 2006$ & 8.0 \\
\hline & Mahurangi Hr & $36^{\circ} 25^{\prime} 54^{\prime \prime} \mathrm{S}, 174^{\circ} 43^{\prime} 03^{\prime \prime} \mathrm{E}$ & 0.0085 & - & 05/10/2006 & 19.2 \\
\hline & Whangarei $\mathrm{Hr}$ & $35^{\circ} 46^{\prime} 43^{\prime} \mathrm{S}, 174^{\circ} 26^{\prime} 08^{\prime \prime} \mathrm{E}$ & 0.0085 & - & $07 / 11 / 2006$ & \\
\hline \multirow[t]{3}{*}{ Mudflat } & Whangateau Hr & $36^{\circ} 18^{\prime} 58^{\prime \prime} \mathrm{S}, 174^{\circ} 45^{\prime} 43^{\prime \prime} \mathrm{E}$ & 0.0085 & - & $27 / 09 / 2006$ & 53.7 \\
\hline & Mahurangi Hr & $36^{\circ} 28^{\prime} 18^{\prime \prime} \mathrm{S}, 174^{\circ} 43^{\prime} 58^{\prime \prime} \mathrm{E}$ & 0.0085 & - & $05 / 10 / 2006$ & 13.7 \\
\hline & Whangarei Hr & $35^{\circ} 46^{\prime} 43^{\prime \prime} \mathrm{S}, 174^{\circ} 26^{\prime} 08^{\prime \prime} \mathrm{E}$ & 0.0085 & - & $07 / 11 / 2006$ & \\
\hline \multirow[t]{3}{*}{ Pneumatophores } & Whangateau Hr & $36^{\circ} 18^{\prime} 58^{\prime \prime} \mathrm{S}, 174^{\circ} 45^{\prime} 43^{\prime \prime} \mathrm{E}$ & 0.1 & - & $27 / 09 / 2006$ & 8.0 \\
\hline & Mahurangi Hr & $36^{\circ} 25^{\prime} 54^{\prime \prime} \mathrm{S}, 174^{\circ} 43^{\prime} 03^{\prime \prime} \mathrm{E}$ & 0.1 & - & $05 / 10 / 2006$ & 19.2 \\
\hline & Whangarei Hr & $35^{\circ} 46^{\prime} 43^{\prime \prime} \mathrm{S}, 174^{\circ} 26^{\prime} 08^{\prime \prime} \mathrm{E}$ & 0.0085 & - & 07/11/2006 & \\
\hline \multirow[t]{2}{*}{ Sandflat } & Whangateau Hr & $36^{\circ} 19^{\prime} 25^{\prime \prime} \mathrm{S}, 174^{\circ} 46^{\prime} 34^{\prime \prime} \mathrm{E}$ & 0.0085 & - & $06 / 10 / 2006$ & 1.7 \\
\hline & Mahurangi Hr & $36^{\circ} 25^{\prime} 54^{\prime \prime} \mathrm{S}, 174^{\circ} 43^{\prime} 03^{\prime \prime} \mathrm{E}$ & & & & 4.4 \\
\hline \multirow[t]{3}{*}{ Seagrass blades } & Mahurangi Hr & $36^{\circ} 25^{\prime} 54^{\prime \prime} \mathrm{S}, 174^{\circ} 43^{\prime} 03^{\prime \prime} \mathrm{E}$ & & & & $<0.5$ \\
\hline & Snells Beach & $36^{\circ} 25^{\prime} 18^{\prime \prime} \mathrm{S}, 174^{\circ} 43^{\prime} 57^{\prime \prime} \mathrm{E}$ & 0.0085 & - & 03/10/2006 & \\
\hline & Whangateau Hr & $36^{\circ} 20^{\prime} 54^{\prime \prime} \mathrm{S}, 174^{\circ} 45^{\prime} 48^{\prime \prime} \mathrm{E}$ & 0.0085 & & $13 / 11 / 2006$ & 4.1 \\
\hline \multirow[t]{3}{*}{ Seagrass sediment } & Mahurangi Hr & $36^{\circ} 25^{\prime} 54^{\prime \prime} \mathrm{S}, 174^{\circ} 43^{\prime} 03^{\prime \prime} \mathrm{E}$ & & & & $<0.5$ \\
\hline & Snells Beach & $36^{\circ} 25^{\prime} 18^{\prime \prime} \mathrm{S}, 174^{\circ} 43^{\prime} 57^{\prime \prime} \mathrm{E}$ & 0.0085 & - & 03/10/2006 & \\
\hline & Whangateau Hr & $36^{\circ} 20^{\prime} 54^{\prime \prime} \mathrm{S}, 174^{\circ} 45^{\prime} 48^{\prime \prime} \mathrm{E}$ & 0.0085 & & $13 / 11 / 2006$ & 4.4 \\
\hline
\end{tabular}


Appendix 1 (continued)

\begin{tabular}{|c|c|c|c|c|c|c|}
\hline Habitat & Location & Coordinates & $\begin{array}{l}\text { Area sampled } \\
\qquad\left(\mathrm{m}^{2}\right)\end{array}$ & $\begin{array}{c}\text { Depth } \\
\text { (m below C.D.) }\end{array}$ & $\begin{array}{l}\text { Collection date } \\
\text { (dd/mm/yy) }\end{array}$ & $\begin{array}{l}\text { Habitat } \\
\text { extent }(\%)\end{array}$ \\
\hline \multicolumn{7}{|l|}{ Intertidal rocky reef } \\
\hline \multirow[t]{3}{*}{ Bare rock } & Mathesons Bay & $36^{\circ} 18^{\prime} 30^{\prime \prime} \mathrm{S}, 174^{\circ} 47^{\prime} 54^{\prime \prime} \mathrm{E}$ & 0.0085 & - & $27 / 09 / 2006$ & 78.4 \\
\hline & Tawharanui & $36^{\circ} 21^{\prime} 49^{\prime \prime} \mathrm{S}, 174^{\circ} 49^{\prime} 35^{\prime \prime} \mathrm{E}$ & 0.0085 & - & 04/10/2006 & 76.7 \\
\hline & Pakiri Beach & $36^{\circ} 15^{\prime} 32^{\prime \prime} \mathrm{S}, 174^{\circ} 45^{\prime} 02^{\prime \prime} \mathrm{E}$ & 0.0085 & - & 28/09/2006 & 35.5 \\
\hline \multirow{3}{*}{$\begin{array}{l}\text { Intertidal coralline } \\
\text { turf }\end{array}$} & Mathesons Bay & $36^{\circ} 18^{\prime} 30^{\prime \prime} \mathrm{S}, 174^{\circ} 47^{\prime} 54^{\prime \prime} \mathrm{E}$ & 0.0085 & - & $27 / 09 / 2006$ & 21.2 \\
\hline & Tawharanui & $36^{\circ} 21^{\prime} 49^{\prime \prime} \mathrm{S}, 174^{\circ} 49^{\prime} 35^{\prime \prime} \mathrm{E}$ & 0.0085 & - & $04 / 10 / 2006$ & 19.3 \\
\hline & Pakiri Beach & $36^{\circ} 15^{\prime} 32^{\prime \prime} \mathrm{S}, 174^{\circ} 45^{\prime} 02^{\prime \prime} \mathrm{E}$ & 0.0085 & - & $28 / 09 / 2006$ & 13.2 \\
\hline \multirow[t]{4}{*}{ Perna canaliculus } & Mathesons Bay & $36^{\circ} 18^{\prime} 30^{\prime \prime} \mathrm{S}, 174^{\circ} 47^{\prime} 54^{\prime \prime} \mathrm{E}$ & & & & $<0.5$ \\
\hline & Ocean Beach & $36^{\circ} 50^{\prime} 21^{\prime \prime} \mathrm{S}, 174^{\circ} 34^{\prime} 20^{\prime \prime} \mathrm{E}$ & 0.0085 & - & $07 / 11 / 2006$ & \\
\hline & Pakiri Beach & $36^{\circ} 15^{\prime} 32^{\prime \prime} \mathrm{S}, 174^{\circ} 45^{\prime} 02^{\prime \prime} \mathrm{E}$ & 0.0085 & - & $28 / 09 / 2006$ & 2.6 \\
\hline & Tawharanui & $36^{\circ} 21^{\prime} 49^{\prime \prime} \mathrm{S}, 174^{\circ} 49^{\prime} 35^{\prime \prime} \mathrm{E}$ & & & & 0.7 \\
\hline \multirow[t]{4}{*}{ Xenostrobus pulex } & Pakiri Beach & $36^{\circ} 15^{\prime} 32^{\prime \prime} \mathrm{S}, 174^{\circ} 45^{\prime} 02^{\prime \prime} \mathrm{E}$ & 0.0085 & - & $28 / 09 / 2006$ & 27.6 \\
\hline & Mathesons Bay & $36^{\circ} 18^{\prime} 30^{\prime \prime} \mathrm{S}, 174^{\circ} 47^{\prime} 54^{\prime \prime} \mathrm{E}$ & 0.0085 & - & $19 / 10 / 2006$ & 0.5 \\
\hline & Ocean Beach & $35^{\circ} 50^{\prime} 21^{\prime \prime} \mathrm{S}, 174^{\circ} 34^{\prime} 20^{\prime \prime} \mathrm{E}$ & 0.0085 & - & $07 / 11 / 2006$ & \\
\hline & Tawharanui & $36^{\circ} 21^{\prime} 49^{\prime \prime} \mathrm{S}, 174^{\circ} 49^{\prime} 35^{\prime \prime} \mathrm{E}$ & & & & 3.3 \\
\hline \multicolumn{7}{|c|}{ Subtidal rocky reef } \\
\hline \multirow{4}{*}{$\begin{array}{l}\text { Carpophyllum } \\
\text { plumosum }\end{array}$} & Elephant Pt & $36^{\circ} 22^{\prime} 12^{\prime \prime} \mathrm{S}, 174^{\circ} 51^{\prime} 56^{\prime \prime} \mathrm{E}$ & - & 2 & $15 / 11 / 2006$ & \\
\hline & Mathesons Bay & $36^{\circ} 18^{\prime} 30^{\prime \prime} \mathrm{S}, 174^{\circ} 47^{\prime} 54^{\prime \prime} \mathrm{E}$ & - & 3.5 & $12 / 10 / 2006$ & 17.1 \\
\hline & Ladder Bay & $36^{\circ} 17^{\prime} 18^{\prime \prime} \mathrm{S}, 174^{\circ} 49^{\prime} 01^{\prime \prime} \mathrm{E}$ & & & & 6.7 \\
\hline & Okakari Pt & $36^{\circ} 15^{\prime} 37^{\prime \prime} \mathrm{S}, 174^{\circ} 45^{\prime} 55^{\prime \prime} \mathrm{E}$ & - & 1.5 & 02/11/2006 & \\
\hline \multirow{4}{*}{$\begin{array}{l}\text { Subtidal coralline } \\
\text { turf }\end{array}$} & Elephant Pt & $36^{\circ} 22^{\prime} 12^{\prime \prime} \mathrm{S}, 174^{\circ} 51^{\prime} 56^{\prime \prime} \mathrm{E}$ & 0.00785 & 2 & $15 / 11 / 2006$ & \\
\hline & Ladder Bay & $36^{\circ} 17^{\prime} 18^{\prime \prime} \mathrm{S}, 174^{\circ} 49^{\prime} 01^{\prime} \mathrm{E}$ & & & & 21.3 \\
\hline & Mathesons Bay & $36^{\circ} 18^{\prime} 30^{\prime \prime} \mathrm{S}, 174^{\circ} 47^{\prime} 54^{\prime \prime} \mathrm{E}$ & 0.00785 & 1.6 & $31 / 10 / 2006$ & 17.1 \\
\hline & Okakari Pt & $36^{\circ} 15^{\prime} 37^{\prime \prime} \mathrm{S}, 174^{\circ} 45^{\prime} 55^{\prime \prime} \mathrm{E}$ & 0.00785 & 1.5 & $02 / 11 / 2006$ & \\
\hline \multirow{4}{*}{$\begin{array}{l}\text { Ecklonia radiata } \\
\text { holdfast }\end{array}$} & Mathesons Bay & $36^{\circ} 18^{\prime} 30^{\prime \prime} \mathrm{S}, 174^{\circ} 47^{\prime} 54^{\prime \prime} \mathrm{E}$ & - & 3.5 & $12 / 10 / 2006$ & 23.7 \\
\hline & Elephant Pt & $36^{\circ} 22^{\prime} 12^{\prime \prime} \mathrm{S}, 174^{\circ} 51^{\prime} 56^{\prime \prime} \mathrm{E}$ & - & 4 & $15 / 11 / 2006$ & \\
\hline & Ladder Bay & $36^{\circ} 17^{\prime} 18^{\prime \prime} \mathrm{S}, 174^{\circ} 49^{\prime} 01^{\prime \prime} \mathrm{E}$ & & & & 21.3 \\
\hline & Okakari Pt & $36^{\circ} 15^{\prime} 37^{\prime \prime} \mathrm{S}, 174^{\circ} 45^{\prime} 55^{\prime \prime} \mathrm{E}$ & - & 1.5 & 02/11/2006 & \\
\hline \multirow{4}{*}{$\begin{array}{l}\text { Ecklonia radiata } \\
\text { fronds }\end{array}$} & Elephant Pt & $36^{\circ} 22^{\prime} 12^{\prime \prime} \mathrm{S}, 174^{\circ} 51^{\prime} 56^{\prime \prime} \mathrm{E}$ & - & 4 & $15 / 11 / 2006$ & \\
\hline & Mathesons Bay & $36^{\circ} 18^{\prime} 30^{\prime \prime} \mathrm{S}, 174^{\circ} 47^{\prime} 54^{\prime \prime} \mathrm{E}$ & - & 3.5 & $12 / 10 / 2006$ & 23.7 \\
\hline & Ladder Bay & $36^{\circ} 17^{\prime} 18^{\prime \prime} \mathrm{S}, 174^{\circ} 49^{\prime} 01^{\prime \prime} \mathrm{E}$ & & & & 21.3 \\
\hline & Okakari Pt & $36^{\circ} 15^{\prime} 37^{\prime \prime} \mathrm{S}, 174^{\circ} 45^{\prime} 55^{\prime \prime} \mathrm{E}$ & - & 1.5 & 02/11/2006 & \\
\hline \multirow[t]{3}{*}{ Rhodophytes } & Ladder Bay & $36^{\circ} 17^{\prime} 18^{\prime \prime} \mathrm{S}, 174^{\circ} 49^{\prime} 01^{\prime \prime} \mathrm{E}$ & & & & $<0.5$ \\
\hline & Mathesons Bay & $36^{\circ} 18^{\prime} 30^{\prime \prime} \mathrm{S}, 174^{\circ} 47^{\prime} 54^{\prime \prime} \mathrm{E}$ & - & 1.6 & $06 / 11 / 2006$ & 6.6 \\
\hline & Okakari Pt & $36^{\circ} 15^{\prime} 37^{\prime \prime} \mathrm{S}, 174^{\circ} 45^{\prime} 55^{\prime \prime} \mathrm{E}$ & - & 1.5 & $02 / 11 / 2006$ & \\
\hline \multicolumn{7}{|c|}{ Subtidal rocky reef } \\
\hline \multirow[t]{4}{*}{ Urchin barrens } & Elephant Pt & $36^{\circ} 22^{\prime} 12^{\prime \prime} \mathrm{S}, 174^{\circ} 51^{\prime} 56^{\prime \prime} \mathrm{E}$ & 0.00785 & 2 & $15 / 11 / 2006$ & \\
\hline & Ladder Bay & $36^{\circ} 17^{\prime} 18^{\prime \prime} \mathrm{S}, 174^{\circ} 49^{\prime} 01^{\prime \prime} \mathrm{E}$ & & & & 49.3 \\
\hline & Mathesons Bay & $36^{\circ} 18^{\prime} 30^{\prime \prime} \mathrm{S}, 174^{\circ} 47^{\prime} 54^{\prime \prime} \mathrm{E}$ & 0.00785 & 0.5 & $31 / 10 / 2006$ & 35.5 \\
\hline & Okakari Pt & $36^{\circ} 15^{\prime} 37^{\prime \prime} \mathrm{S}, 174^{\circ} 45^{\prime} 55^{\prime \prime} \mathrm{E}$ & 0.00785 & 1.5 & $02 / 11 / 2006$ & \\
\hline \multicolumn{7}{|l|}{ Sandy beach } \\
\hline \multirow{3}{*}{$\begin{array}{l}\text { Intertidal sands } \\
\text { (exposed) }\end{array}$} & Pakiri Beach & $36^{\circ} 14^{\prime} 38^{\prime \prime} \mathrm{S}, 174^{\circ} 43^{\prime} 41^{\prime \prime} \mathrm{E}$ & 0.0513 & - & $29 / 09 / 2006$ & \\
\hline & Ocean Beach (s) & $35^{\circ} 50^{\prime} 21^{\prime \prime} \mathrm{S}, 174^{\circ} 34^{\prime} 20^{\prime \prime} \mathrm{E}$ & 0.00256 & - & $07 / 11 / 2006$ & \\
\hline & Ocean Beach (n) & $35^{\circ} 49^{\prime} 36^{\prime \prime} \mathrm{S}, 36^{\circ} 33^{\prime} 48^{\prime \prime} \mathrm{E}$ & 0.0171 & - & $07 / 11 / 2006$ & \\
\hline \multirow{3}{*}{$\begin{array}{l}\text { Intertidal sands } \\
\text { (mod. exposed) }\end{array}$} & Omaha Beach & $36^{\circ} 20^{\prime} 24^{\prime \prime} \mathrm{S}, 174^{\circ} 46^{\prime} 55^{\prime \prime} \mathrm{E}$ & 0.0513 & - & 06/10/2006 & \\
\hline & Wenderholm Bch & $36^{\circ} 31^{\prime} 51^{\prime \prime} \mathrm{S}, 174^{\circ} 42^{\prime} 50^{\prime \prime} \mathrm{E}$ & 0.0513 & - & $10 / 10 / 2006$ & \\
\hline & Mathesons Beach & $36^{\circ} 18^{\prime} 30^{\prime \prime} \mathrm{S}, 174^{\circ} 47^{\prime} 54^{\prime \prime} \mathrm{E}$ & 0.0085 & - & 09/10/2006 & \\
\hline \multirow{2}{*}{$\begin{array}{l}\text { Mod. exposed } \\
\text { wrack }\end{array}$} & Mathesons Beach & $36^{\circ} 18^{\prime} 30^{\prime \prime} \mathrm{S}, 174^{\circ} 47^{\prime} 54^{\prime \prime} \mathrm{E}$ & 0.0287 & - & $25 / 10 / 2006$ & $<0.5$ \\
\hline & Wenderholm Beach & $36^{\circ} 31^{\prime} 51^{\prime \prime} \mathrm{S}, 174^{\circ} 42^{\prime} 50^{\prime \prime} \mathrm{E}$ & 0.0287 & - & $25 / 10 / 2006$ & $<0.5$ \\
\hline \multirow{3}{*}{$\begin{array}{l}\text { Intertidal sands } \\
\text { (sheltered) }\end{array}$} & Martins Beach & $36^{\circ} 27^{\prime} 00^{\prime \prime} \mathrm{S}, 174^{\circ} 45^{\prime} 51^{\prime \prime} \mathrm{E}$ & 0.0085 & - & 03/10/2006 & \\
\hline & Scandretts Beach & $36^{\circ} 26^{\prime} 34^{\prime \prime} \mathrm{S}, 174^{\circ} 46^{\prime} 26^{\prime \prime} \mathrm{E}$ & 0.0085 & - & $17 / 10 / 2006$ & \\
\hline & Algies Bay & $36^{\circ} 26^{\prime} 00^{\prime \prime} \mathrm{S}, 174^{\circ} 44^{\prime} 39^{\prime \prime} \mathrm{E}$ & 0.0085 & - & 19/10/2006 & \\
\hline Sheltered wrack & Martins Beach & $36^{\circ} 27^{\prime} 00^{\prime \prime} \mathrm{S}, 174^{\circ} 45^{\prime} 51^{\prime \prime} \mathrm{E}$ & 0.0287 & - & 03/10/2006 & $<0.5$ \\
\hline & Scandretts Beach & $36^{\circ} 26^{\prime} 34^{\prime \prime} \mathrm{S}, 174^{\circ} 46^{\prime} 26^{\prime \prime} \mathrm{E}$ & 0.0287 & & $17 / 10 / 2006$ & $<0.5$ \\
\hline
\end{tabular}


Appendix 1 (continued)

\begin{tabular}{|c|c|c|c|c|c|c|}
\hline Habitat & Location & Coordinates & $\begin{array}{l}\text { Area sampled } \\
\qquad\left(\mathrm{m}^{2}\right)\end{array}$ & $\begin{array}{c}\text { Depth } \\
\text { (m below C.D.) }\end{array}$ & $\begin{array}{l}\text { Collection date } \\
\text { (dd/mm/yy) }\end{array}$ & $\begin{array}{c}\text { Habitat } \\
\text { extent }(\%)\end{array}$ \\
\hline \multicolumn{7}{|c|}{ Subtidal soft sediments } \\
\hline $10 \mathrm{~m}$ deep sand & $\begin{array}{l}\text { Omaha Bay } \\
\text { Pakiri } \\
\text { Bostaquet Bay }\end{array}$ & $\begin{array}{l}36^{\circ} 20^{\prime} 00^{\prime \prime} \mathrm{S}, 174^{\circ} 47^{\prime} 26^{\prime \prime} \mathrm{E} \\
36^{\circ} 14^{\prime} 57^{\prime \prime} \mathrm{S}, 174^{\circ} 44^{\prime} 38^{\prime \prime} \mathrm{E} \\
36^{\circ} 26^{\prime} 45^{\prime \prime} \mathrm{S}, 174^{\circ} 51^{\prime} 30^{\prime \prime} \mathrm{E}\end{array}$ & $\begin{array}{l}0.0085 \\
0.0085 \\
0.0085\end{array}$ & $\begin{array}{l}10 \\
10 \\
10\end{array}$ & $\begin{array}{l}20 / 10 / 2006 \\
01 / 11 / 2006 \\
14 / 11 / 2006\end{array}$ & 11.7 \\
\hline $20 \mathrm{~m}$ deep sand & $\begin{array}{l}\text { Omaha Bay } \\
\text { Pakiri } \\
\text { Bostaquet Bay }\end{array}$ & $\begin{array}{l}36^{\circ} 19^{\prime} 30^{\prime \prime} \mathrm{S}, 174^{\circ} 48^{\prime} 17^{\prime \prime} \mathrm{E} \\
36^{\circ} 14^{\prime} 39^{\prime \prime} \mathrm{S}, 174^{\circ} 44^{\prime} 56^{\prime \prime} \mathrm{E} \\
36^{\circ} 26^{\prime} 48^{\prime \prime} \mathrm{S}, 174^{\circ} 51^{\prime} 39^{\prime \prime} \mathrm{E}\end{array}$ & $\begin{array}{l}0.0085 \\
0.0085 \\
0.0085\end{array}$ & $\begin{array}{l}20 \\
20 \\
20\end{array}$ & $\begin{array}{l}20 / 10 / 2006 \\
01 / 11 / 2006 \\
14 / 11 / 2006\end{array}$ & 11.7 \\
\hline $2 \mathrm{~m}$ deep sand & $\begin{array}{l}\text { Omaha Bay } \\
\text { Bostaquet Bay } \\
\text { Pakiri }\end{array}$ & $\begin{array}{l}36^{\circ} 20^{\prime} 06^{\prime \prime} \mathrm{S}, 174^{\circ} 46^{\prime} 52^{\prime \prime} \mathrm{E} \\
36^{\circ} 26^{\prime} 28^{\prime \prime} \mathrm{S}, 174^{\circ} 51^{\prime} 28^{\prime \prime} \mathrm{E} \\
36^{\circ} 15^{\prime} 06^{\prime \prime} \mathrm{S}, 174^{\circ} 44^{\prime} 24^{\prime \prime} \mathrm{E}\end{array}$ & $\begin{array}{l}0.0085 \\
0.0085 \\
0.0085\end{array}$ & $\begin{array}{l}2 \\
2 \\
2\end{array}$ & $\begin{array}{l}20 / 10 / 2006 \\
14 / 11 / 2006 \\
04 / 12 / 2006\end{array}$ & 11.7 \\
\hline $5 \mathrm{~m}$ deep sand & $\begin{array}{l}\text { Omaha Bay } \\
\text { Pakiri } \\
\text { Bostaquet Bay }\end{array}$ & $\begin{array}{l}36^{\circ} 20^{\prime} 06^{\prime \prime} \mathrm{S}, 174^{\circ} 46^{\prime} 58^{\prime \prime} \mathrm{E} \\
36^{\circ} 15^{\prime} 03^{\prime \prime} \mathrm{S}, 174^{\circ} 44^{\prime} 31^{\prime \prime} \mathrm{E} \\
36^{\circ} 26^{\prime} 30^{\prime \prime} \mathrm{S}, 174^{\circ} 51^{\prime} 28^{\prime \prime} \mathrm{E}\end{array}$ & $\begin{array}{l}0.0085 \\
0.0085 \\
0.0085\end{array}$ & $\begin{array}{l}5 \\
5 \\
5\end{array}$ & $\begin{array}{l}20 / 10 / 2006 \\
01 / 11 / 2006 \\
14 / 11 / 2006\end{array}$ & 11.7 \\
\hline $\begin{array}{l}\text { Estuarine channel } \\
\text { hash }\end{array}$ & $\begin{array}{l}\text { Whangateau Hr } \\
\text { Omaha Bay }\end{array}$ & $\begin{array}{l}36^{\circ} 19^{\prime} 13^{\prime \prime} \mathrm{S}, 174^{\circ} 46^{\prime} 40^{\prime \prime} \mathrm{E} \\
36^{\circ} 20^{\prime} 54^{\prime \prime} \mathrm{S}, 174^{\circ} 48^{\prime} 00^{\prime \prime} \mathrm{E}\end{array}$ & $\begin{array}{l}0.0085 \\
0.0085\end{array}$ & $\begin{array}{c}3.1 \\
13.3\end{array}$ & $\begin{array}{l}31 / 10 / 2006 \\
31 / 10 / 2006\end{array}$ & 11.8 \\
\hline Atrina zelandica & $\begin{array}{l}\text { Bostaquet Bay } \\
\text { Martins Bay } \\
\text { Omaha Bay }\end{array}$ & $\begin{array}{l}36^{\circ} 26^{\prime} 30^{\prime \prime} \mathrm{S}, 174^{\circ} 51^{\prime} 28^{\prime \prime} \mathrm{E} \\
36^{\circ} 26^{\prime} 50^{\prime \prime} \mathrm{S}, 174^{\circ} 46^{\prime} 01^{\prime \prime} \mathrm{E} \\
36^{\circ} 20^{\prime} 54^{\prime \prime} \mathrm{S}, 174^{\circ} 48^{\prime} 00^{\prime \prime} \mathrm{E}\end{array}$ & $\begin{array}{l}- \\
-\end{array}$ & $\begin{array}{l}7 \\
2\end{array}$ & $\begin{array}{l}07 / 12 / 2006 \\
20 / 11 / 2006\end{array}$ & 5.2 \\
\hline
\end{tabular}

Editorial responsibility: Kenneth Heck, Dauphin Island, Alabama, USA
Submitted: September 12, 2008; Accepted: March 27, 2009 Proofs received from author(s): May 18, 2009 